\title{
Carcinoma of Prostate: Response of Plasma Luteinizing Hormone and Testosterone to Oestrogen Therapy
}

\author{
A. ALDER, * M.B., B.S., F.R.C.S., F.R.A.c.s., F.A.C.s. ; H. BURGER, $†$ M.D., M.R.A.C.P. ; J. DAVIS, $\dagger$ B.SC. \\ A. DULMANIS, $\dagger$ M.SC. ; B. HUDSON, $\ddagger$ M.D., PH.D., F.R.C.P., F.R.A.C.P. ; G. SARFATY, $\S$ M.D. \\ W. STRAFFON, * M.B., B.S., F.R.C.S.
}

Brit. med. F., 1968, 1, 28-30

Oestrogen therapy has become well established as a method of treatment of local and metastatic prostatic carcinoma, following the pioneering investigations of Huygins and his co-workers (1939, 1940, 1941).

In a large majority of affected patients prostatic tumours and their metastases are hormone-sensitive and endocrine therapy has been undertaken with the purpose of altering the hormonal milieu and, specifically, of lowering androgen levels. Orchidectomy and/or the administration of oestrogens have become cornerstones of treatment, but relatively little is known of their effects on the secretion of pituitary gonadotrophins and of testosterone, the major physiologically active androgen in man. Furthermore, the results of hypophysectomy for prostate cancer, especially in patients who have relapsed after oestrogen and orchidectomy, have been encouraging enough to warrant further exploration of this procedure, particularly at an earlier stage of the disease. The following studies were undertaken, firstly to gain information about the effects of oestrogen treatment specifically on testosterone and luteinizing hormone levels in patients with prostatic cancer, and, secondly, to provide a basis for comparison of the effects of this treatment with those of hypophysectomy done as the initial procedure for metastatic disease.

\section{Methods}

Nine patients aged $65-84$ were studied. The diagnosis of prostatic carcinoma was made by histological examination of tissue obtained at transurethral resection. By adopting the criteria of Whitmore (1956) the patients could be classified as follows: stage I, four patients; stage II, two ; stage III, one; and stage IV, two. After diagnosis blood was drawn for determination of plasma testosterone and luteinizing hormone concentration; in seven subjects plasma growth hormone and cortisol were measured after insulin-induced hypoglycaemia.

Oestrogen treatment was then begun with stilboestrol 90 mg./day for seven days in most subjects ; thereafter a maintenance dose of $30 \mathrm{mg}$./day was given. Blood for testosterone and luteinizing hormone was drawn daily for the first three days of therapy, again at the end of the first week, and again at about three weeks. Subsequently specimens were obtained at intervals of one to three months in most subjects. In two patients the insulin hypoglycaemia test was repeated after two weeks of stilboestrol treatment.

Plasma testosterone was measured by the double isotope dilution derivative assay of Hudson et al. (1963). Luteinizing hormone was measured by radio-immunoassay (Burger et al., 1967). Briefly, this method uses paper chromato-electrophoresis for separation of antibody-bound and free labelled

* Department of Urology, Prince Henry's Hospital, Melbourne, Australia. + Medica: Research Centre, Prince Henry's Hospital, Melbourne. $\uparrow$ Medica: Research Centre, P

$\$$ Mancer Institute, Melbourne. antigen. A human pituitary luteinizing hormone preparation was used as the standard; its potency, in terms of the Second International Reference preparation, is $10 \mathrm{i} . \mathrm{u} . / \mu \mathrm{g}$. The precision of the method is such that within a single assay the coefficient of variation is $7-12 \%$ in the range of concentrations reported here. Successive samples from individual patients were measured in duplicate, within one assay on at least two occasions, and the data reported represent mean values so obtained.

Growth hormone was measured by radio-immunoassay, either by the paper chromato-electrophoretic technique of Glick ot al. (1963) or by the solid phase disc immunoassay technique of Catt et al. (1967). Plasma cortisol was determined by a modification of the method of Mattingly (1962).

\section{Results}

The effects of oestrogen treatment on the plasma concentration of testosterone and luteinizing hormone are shown in Table I and the Chart. The mean basal luteinizing hormone and testosterone levels were 2.8 (range $2.0-3.7$ ) i.u. $/ 100 \mathrm{ml}$. and $725(470-1,020) \mathrm{m} \mu \mathrm{g} . / 100 \mathrm{ml}$. respectively. The mean plasma luteinizing hormone level ( \pm S.E.) in a group of 46 normal males aged 18-75 was $2.25( \pm 0.16)$ i.u./100 ml., and the mean testosterone concentration ( \pm S.E.) in a group of 59 normal males aged 17-60 years was $690( \pm 20) \mathrm{m} \mu \mathrm{g} . / 100 \mathrm{ml}$. (Hudson et al., 1967). The significance of differences between days (Table I) was calculated by means of Student's $t$ test.

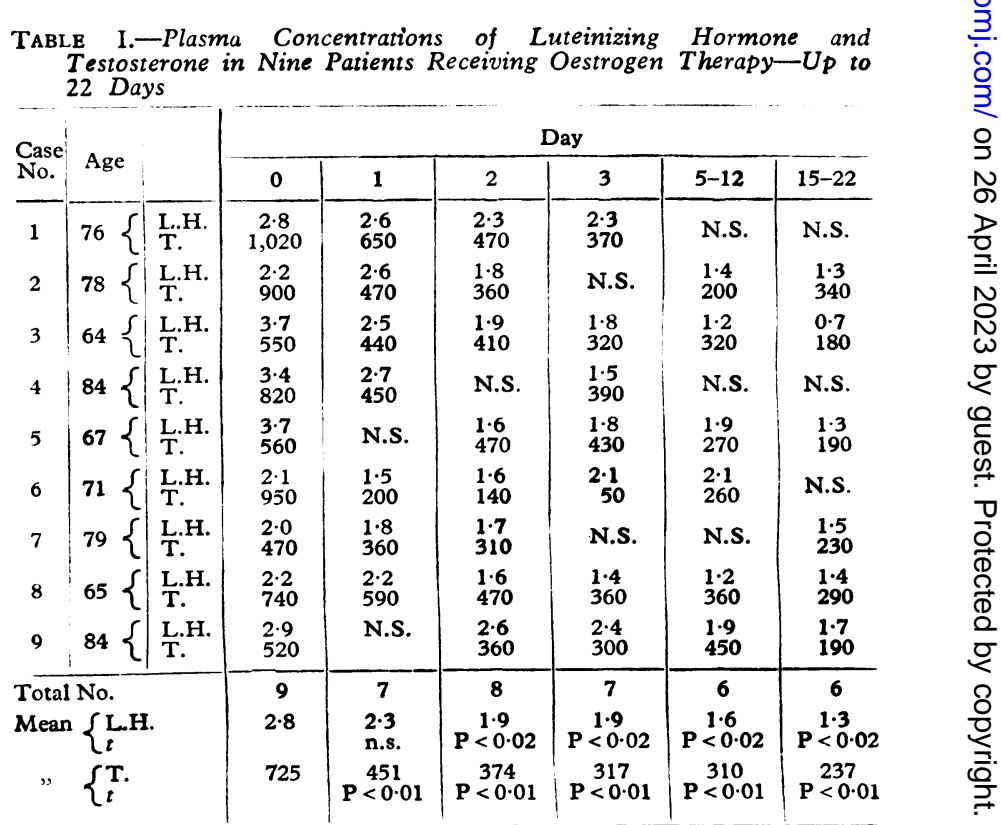

L.H. = Luteinizing hormone (i.u. $/ 100 \mathrm{ml}$.). T. $=$ Testosterone $(\mathrm{m} \mu \mathrm{g} . / 100 \mathrm{ml}$. N.S. $=$ No specimen obtainable. n.s. $=$ Not significant. $t=$ Significance of difference between days calculated by means of Student's $t$ test. 
After one day of oestrogen therapy luteinizing hormone had fallen by $17.9 \%$ of the basal level, while testosterone had fallen by $37.8 \%$. After two days the respective decreases were $32.1 \%$ and $48.5 \%$, while after two to three weeks of treatment luteinizing hormone had decreased by $53.5 \%$ and testosterone by $67.2 \%$.
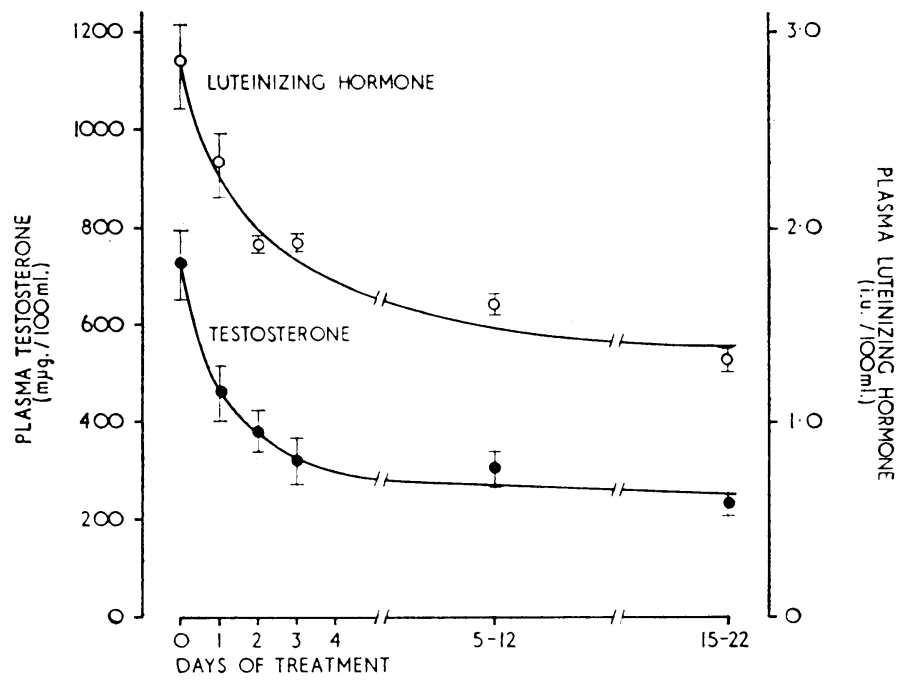

Mean concentration ( \pm S.E.) of plasma luteinizing hormone $(\mathrm{O}-\mathrm{O})$ and testosterone (-O) in nine patients with prostatic carcinoma during the first three weeks of treatment with large doses of stilboestrol.

Four patients have been followed for periods up to 37 weeks after the beginning of oestrogen therapy : it is notable that there has been fluctuation in the levels of testosterone and luteinizing hormone (Table II); and in only one patient (Case 3 ) has the luteinizing hormone level become undetectable and the testosterone fallen into the normal female range. In Case 2 the testosterone concentration began to rise again within three weeks of starting oestrogen, and has shown considerable variation over a 32 -week period.

Table II.-Plasma Concentrations of Luteinizing Hormone and Testosterone in Four Patients Receiving Oestrogen Therapy-After 7 to 37 Weeks

\begin{tabular}{|c|c|c|c|c|}
\hline \multirow{2}{*}{ Case No. } & & \multicolumn{3}{|c|}{ Weeks of Treatment } \\
\hline & & $7-10$ & $20-24$ & $32-37$ \\
\hline 1 & $\begin{array}{l}\text { L.H. } \\
\text { T. }\end{array}$ & $\begin{array}{l}1.2 \\
290\end{array}$ & $\begin{array}{l}2 \cdot 0 \\
220\end{array}$ & $\begin{array}{l}0 \cdot 6 \\
310\end{array}$ \\
\hline 2 & $\begin{array}{l}\text { L.H. } \\
\text { T. }\end{array}$ & $\begin{array}{l}1 \cdot 3 \\
480\end{array}$ & $\begin{array}{l}2.3 \\
150\end{array}$ & $\begin{array}{l}1 \cdot 3 \\
520\end{array}$ \\
\hline 3 & $\begin{array}{l}\text { L.H. } \\
\text { T. }\end{array}$ & & & $\begin{array}{l}0 \cdot 7 \\
60\end{array}$ \\
\hline 9 & $\begin{array}{l}\text { L.H. } \\
\text { T. }\end{array}$ & & $\begin{array}{l}2.7 \\
100\end{array}$ & \\
\hline
\end{tabular}

L.H. = Luteinizing hormone (i.u. $/ 100 \mathrm{ml}$.). T. $=$ Testosterone $(\mathrm{m} \mu \mathrm{g} . / 100 \mathrm{ml}$.$) .$

Two patients temporarily discontinued their oestrogen treatment. One (Case 5) omitted his tablets between the twelfth and eighteenth weeks of treatment; after this his testosterone had increased to $380 \mathrm{~m} \mu \mathrm{g} . / 100 \mathrm{ml}$., while the luteinizing hormone had risen to 2.7 i.u./100 ml.; after eight further weeks of treatment on $60 \mathrm{mg}$. of stilboestrol per day, testosterone concentration was still $290 \mathrm{~m} u \mathrm{~g} . / 100 \mathrm{ml}$. He has since been subjected to orchidectomy, with a fall of testosterone to 140 to $150 \mathrm{~m} \mu \mathrm{g} . / 100 \mathrm{ml}$. The other patient (Case 6) omitted his stilboestrol for two weeks only; the testosterone increased from 260 to $860 \mathrm{~m} \mu \mathrm{g} . / 10 \mathrm{ml}$, while the luteinizing hormone rose from 2.1 to 3.1 i.u./100 ml.; continued oestrogen therapy, in a dose of $30 \mathrm{mg}$./day, led to a fall in luteinizing hormone level, but the testosterone was again poorly suppressed even after some weeks.

With regard to the response of growth hormone and A.C.T.H. to insulin-induced hypoglycaemia, in the four subjects in whom a fall of blood sugar greater than $50 \%$ of the fasting level was obtained there was a rise in plasma human growth hormone (range of increment 14.2 to 47.0 $\mathrm{m}_{\mu} \mathrm{g} . / \mathrm{ml}$.). In three of these subjects plasma cortisol also rose (increments of 10,28 , and $13 \mu \mathrm{g} . / 100 \mathrm{ml}$.), whereas in one the cortisol fell. Two subjects had a second insulinhypoglycaemia test after 12 days and eight weeks of oestrogen therapy respectively. In the former, inadequate hypoglycaemia was achieved on each occasion; but, in the latter, normal responses of human growth hormone and cortisol were seen on both occasions (Table III).

TABLE III.-Response of Plasma Growth Hormone and Cortisol to Insulin Hypoglycaemia Before and During Oestrogen Therapy

\begin{tabular}{|c|c|c|c|c|}
\hline Case No. & $\begin{array}{l}\text { Fall in } \\
\text { Blood } \\
\text { Sugar }\end{array}$ & $\underset{\substack{\text { (m.G.H./mi.) } \\
\text { (Increment) }}}{\text { H.H. }}$ & $\begin{array}{c}\text { Cortisol } \\
\text { ( } \mu \mathrm{g} . / 100 \mathrm{ml} .) \\
\text { (Increment) }\end{array}$ & Treatment \\
\hline 2 & $\begin{array}{l}69 \% \\
54 \%\end{array}$ & $\begin{array}{l}47 \\
47\end{array}$ & $\begin{array}{l}10 \\
51\end{array}$ & $\begin{array}{c}\text { Nil } \\
\text { Stilboestrol } \\
90 \mathrm{mg} / \text { day }\end{array}$ \\
\hline 3 & $\begin{array}{l}33 \% \\
48 \%\end{array}$ & $\begin{array}{r}2 \cdot 7 \\
21 \cdot 4\end{array}$ & $\underset{5}{\mathrm{Nil}}$ & $\begin{array}{c}\mathrm{Nil} \\
\text { Stilboestrol } \\
90 \mathrm{mg} / \mathrm{day}\end{array}$ \\
\hline
\end{tabular}

\section{Discussion}

The first detailed study of the effects of oestrogen therapy on hormone excretion in prostatic cancer was reported by Birke et al. (1955). They measured the excretion of " androgen metabolites" in the urine, and showed that these were completely suppressed in five days by treatment with stilboestrol $30 \mathrm{mg}$. daily. Their investigations did not include the measurement of pituitary gonadotrophins.

The development of sensitive and specific assay methods for testosterone and luteinizing hormone in human plasma has permitted the study of the response of these hormones to oestrogen therapy of prostatic carcinoma. Furthermore, it has been possible to show that large pharmacological doses of oestrogens acutely suppress both hormones in an approximately parallel manner.

Though acute suppression has been shown in all the patients studied, this was not complete, nor was it necessarily sustained. Thus in no patient has the plasma testosterone been suppressed to undetectable levels, and in only two has the luteinizing hormone concentration fallen below the level of sensitivity of the method. The rate of suppression of testosterone in general confirms that reported previously for oestrogens and synthetic androgens (Coppage and Cooner, 1965 : Hudson et al., 1967) and is in contrast with the report of Birke et al. (1955). The failure of complete suppression is in agreement with the findings of Forchielli et al. (1965), who showed that after 21 to 164 days of treatment with ethinyloestradiol in normal men the plasma testosterone was still $200 \mathrm{~m}_{\mu} \mathrm{g} . / 100 \mathrm{ml}$.

Only one previous report (Odell et al., 1966) contains data concerning the effect of oestrogen on plasma luteinizing hormone levels : three normal males showed a mean decrease of $60 \%$ after one day's treatment with ethinyloestradiol. It is of interest that these authors also showed in a postmenopausal woman that luteinizing hormone levels, though suppressed by $60 \%$ after one day's treatment, did not fall further after five days, and the level remained at 3.4 i.u./100 ml. (Odell et al., 1967).

The patients reported here have not yet been followed long enough to allow any conclusion regarding the correlation between the clinical response to treatment and either the initial hormone levels or the degree of suppression. Six of the patients have been followed for more than 20 weeks, and in only one has the disease progressed. After 26 weeks his plasma testosterone level was $290 \mathrm{~m} \mu \mathrm{g} . / 100 \mathrm{ml}$., while the luteinizing hormone was undetectable. 
Though the data in the first three weeks of oestrogen therapy would be consistent with an effect of oestrogen on testicular function mediated through the pituitary, the later observations showing discrepancies between luteinizing hormone and testosterone levels would suggest that the effects are complex and that oestrogens may have a direct effect on the testes independently of the pituitary. Such effects have been demonstrated in experimental animals-for example, by Samuels et al. (1964). It is also conceivable that failure of complete suppression could be accounted for by protein-binding phenomena, though these have not been shown to be significant for luteinizing hormone or for testosterone.

The investigation also demonstrates that oestrogen therapy does not suppress pituitary production of growth hormone or of A.C.T.H.; it thus gives further support to the belief that the place of early hypophysectomy in the treatment of metastatic cancer of the prostate warrants further study.

\section{Summary}

Nine patients with carcinoma of the prostate have been treated with large doses of oestrogens, and their plasma concentrations of luteinizing hormone and testosterone have been measured during treatment. There was an acute decrease in the levels of both hormones, so that after two to three weeks of treatment luteinizing hormone concentration had fallen by $53.5 \%$ and testosterone by $67.2 \%$. This suppression was not sustained in all cases. It is concluded that though the acute effects of oestrogens on the suppression of androgen produc- tion may be mediated through the pituitary the effects are in general more complex, and escape from suppression may occur.

This work was supported by grants from the Australian Research Grants Committee and the National Health and Medical Research Council. We are grateful to Dr. K. J. Catt for helpful discussion, to Miss J. Spinks for assistance with the growth hormone assays, and to Dr. J. McKenzie for the measurement of plasma cortisol.

Requests for reprints should be addressed to Dr. Henry Burger.

\section{REFERENCES}

Birke, G., Franksson, C., and Plantin, L.-O. (1955). Acta chir. scand., 109, $1,129$.

Burger, H. G., Oliver, J. R., Davis, J., and Catt, K. J. (1967). Submitted for publication.

Catt, K. J., Niall, H. D., and Tregear, G. W. (1967). F. Lab. clin. Med. In press.

Coppage, W. S., jun., and Cooner, A. E. (1965). New Engl. F. Med., 273, 902.

Forchielli, E et al. (1965). Acta endocr. (Kbh), 50, 51.

Glick, S. M., Roth, J., Yalow, R. S., and Berson, S. A. (1963). Nature (Lond.), 199, 784

Hudson, B., Coghlan, J. P., and Dulmanis, A. (1967). Ciba Foundation Colloquia on Endocrinology, vol. 16, p. 140. London.

Wintour, M., and Ekkel, I. (1963). Aust. f. exp. Biol. med. Sci., 41, 235 .

Huggins, C., and Clark, P. J. (1940). F. exp. Med., 72, 747.

_ and Hodges, C. V. (1941). Cancer Res., 1, 293.

Masina, M. H., Eichelberger, L., and Wharton, J. D. (1939) 7. exp. Med., 70, 543

Mattingly, D. (1962), 7, clin. Path., 15, 374.

Odell, W. D., Ross, G. T., and Rayford, P. L. (1966). Metabolism, 15, 287.

- (1967). 7. clin. Invest., 46, 248.

Samuels, L. T., Short, J. G., and Huseby, R. A. (1964). Acta endocr (Kbh.), 45, 487

Whitmore, W. F., jun. (1956). Amer. F. Med., 21, 697

\title{
Hypocholesterolaemic Effect of Bengal Gram : a Long-term Study in Man*
}

\author{
K. S. MATHUR, † M.D., F.R.C.P., F.A.M.S., F.N.I. ; M. A. KHAN, $\ddagger$ M.D. ; R. D. SHARMA, $§$ PH.D.
}

Brit. med. F., 1968, 1, 30-31

The frequent association of hypercholesterolaemia with ischaemic heart disease has stimulated search for agents which reduce the cholesterol level in the blood. Our earlier studies have shown that Bengal gram, or "chana" (Cicer arietinum), significantly lowers experimentally induced high levels of cholesterol in both serum and tissues of albino rats (Mathur et al., 1963, 1964) and rabbits (Mathur et al., 1965). A longterm study extending to 67 weeks in man has now been undertaken to assess the hypocholesterolaemic effect of Bengal gram.

\section{Material and Methods}

Thirty male subjects who were free from any systemic disease were studied. Their ages ranged from 15 to 50 years (mean 33.5 years). Their mean weight was $117.2 \pm 24.6 \mathrm{lb}$. $(54 \pm 11.2$ kg.). They were divided into two groups.

Group 1.-Twenty subjects were given "low-fat diet" containing $10 \mathrm{~g}$. of fat for two weeks. Lipid studies were then made to determine the basal values. They were then fed on

- From the Department of Medicine, S. N. Medical College, Agra, India. Financial assistance for this work was provided by the Indian Council of Medical Research.

+ Professor and Head of the Department of Medicine.

$\neq$ Research Fellow.

$\$$ Research Officer.
" high-fat diet" containing $156 \mathrm{~g}$. of butter-fat and supplying 2,812 calories daily. After 10 weeks of high-fat diet, when the serum-lipid levels had become stabilized, they were put on " high-fat + Bengal gram diet" by substituting Bengal gram for wheat-flour and other cereals while maintaining the quantity of butter-fat and total calories at the same level. They were observed on this diet for the next 55 weeks.

Group 2.-Ten subjects were put on low-fat diet for the first two weeks. They were then given the routine hospital diet consisting of $35 \mathrm{~g}$. of fat and supplying 2,756 calories, and were observed for the same period as in group 1 .

The composition of the various diets is given in Table I.

TABLE I.-Composition of Diet

\begin{tabular}{|c|c|c|c|c|c|c|c|}
\hline \multirow{2}{*}{ Diet } & \multirow{2}{*}{$\begin{array}{c}\text { Total } \\
\text { Calories }\end{array}$} & \multicolumn{2}{|c|}{ Carbohydrate } & \multicolumn{2}{|c|}{ Proteins } & \multicolumn{2}{|c|}{ Fat } \\
\hline & & G. & Cal. \% & G. & Cal. \% & G. & Cal. \% \\
\hline $\begin{array}{l}\text { Low-fat } \quad . \\
\text { High-fat } \quad \text { - } \\
\text { Bengal gram } \\
\text { Hospital } \quad \text {. }\end{array}$ & $\begin{array}{l}2,730 \\
2,812 \\
2,831 \\
2,756\end{array}$ & $\begin{array}{l}550 \\
290 \\
247 \\
500\end{array}$ & $\begin{array}{l}80 \cdot 7 \\
42 \cdot 0 \\
35 \cdot 1 \\
72 \cdot 6\end{array}$ & $\begin{array}{r}110 \\
57 \\
85 \\
110\end{array}$ & $\begin{array}{r}16 \cdot 0 \\
8 \cdot 1 \\
12 \cdot 0 \\
16 \cdot 1\end{array}$ & $\begin{array}{r}10 \\
156 \\
167 \\
35\end{array}$ & $\begin{array}{r}3 \cdot 3 \\
49 \cdot 9 \\
52 \cdot 9 \\
11 \cdot 3\end{array}$ \\
\hline
\end{tabular}

Blood samples were collected in the morning at weekly intervals throughout the experiment. They were analysed for serum total cholesterol and free and ester cholesterol by the techniques of Zak et al. (1954), for serum lipid phosphorus by 